\title{
Semi-peripheral financialisation and social reproduction: the case of Portugal ${ }^{*}$
}

\author{
Ana C. Santos ${ }^{\dagger}$, João Rodrigues ${ }^{\ddagger}$, Nuno Teles ${ }^{\S}$
}

Forthcoming in: New Political Economy, DOI: 10.1080/13563467.2017.1371126

\begin{abstract}
Portugal, a semi-peripheral country within the world economy, has followed similar and distinct financialisation processes to those of core countries. This article reflects on the factors that have shaped social reproduction in Portugal by examining the differentiated ways through which finance has interacted with the provision of housing, pensions and water and their variegated impacts. Based on these three case studies, the article discusses the constraints on, and pressures for, continued expansion of finance in the aftermath of the Global Financial Crisis. It underlines the subordinated and uneven nature of Portuguese semi-peripheral financialisation, the role of European integration in its unfolding, and concludes that the promotion of the interests of finance located in major advanced capitalist countries, and of the national and international institutions under their influence, has resulted in growing social and spatial inequalities.
\end{abstract}

Key words: Financialisation, semi-periphery, social reproduction, systems of provision, Portugal, housing, pensions, water 


\section{Introduction}

Financialisation, broadly understood as the rise of the economic and political power of finance in the economy and society (e.g. Epstein 2005), has become one of the most studied subjects within political economy (and other social sciences) in recent years. The processes leading to the rise of finance have already been identified and examined from varied perspectives (for a review see van den Zwan 2014). Generically, these processes include privatisation, deregulation and market-led reregulation of financial activities, allowing the penetration of finance into ever more areas of economic and social life; the expansion and proliferation of different types of financial assets; the primacy of financial interests and imperatives in capital accumulation, increasing income inequality arising out of the weight of financial rewards; consumer-led booms based on credit, and so forth (Fine 2010).

However, financialisation studies have mainly focused on the most mature capitalist countries of the centre, taking the USA and the UK as archetypes of financialised economies and societies (e.g. Epstein 2005). Interest in the varied nature of the rise of finance in other geographical contexts is now emerging (e.g. Becker et al. 2010; Orsi and Solari 2010; Gambarotto and Solari 2015; Rodrigues et al. 2016a). This article aims to contribute to this recent literature by examining the differentiated ways in which finance interacts with various domains of social reproduction - housing, pensions and water provision - and from the perspective of a semi-periphery within the world economy, Portugal.

Taking as its point of departure the concept of semi-peripheral financialisation developed in Rodrigues et al. (2016a), underlining the intermediate position of the Portuguese economy worldwide and the predominance of bank loanable capital vis-à-vis that of capital markets, this article aims at further elaborating on the semi-peripheral nature of financialisation processes, both at the conceptual and empirical levels. Following on Lapavitsas (2013) and Lapavitsas and Powell (2014), it builds on the notion of 'subordinated financialisation', according to which peripheral countries are compelled to join an increasingly financialised world economy, through formal and informal pressures, mainly by opening themselves up to financial flows. Following Fine and Saad-Filho (2016: 12), it builds on the notion of 'variegated financialisation', according to which 'financialization feeds in part by transforming economic and social activity' whereby 'the extent and influence of financialization across the various elements of economic and social reproduction are highly contingent, reinforcing the variegated nature of outcomes'. And based on the Systems of Provision approach (Bayliss et al. 2013), it analyses three distinctive sectors, giving due account of the nature of the good or service provided, and the particular structures, agents, processes and relations that characterise the entire chain of production, allowing for further theorising of financialisation as a heterogeneous process producing variegated outcomes. ${ }^{5}$ The study of the impact of finance on given systems of provision in a semi-periphery permits further illustration of the interplay between financial interests and sector-specific structures, agents, processes and relations, and elaborate on the plasticity of finance to adapt to sector-specific conditions, resulting 
in variegated outcomes due to the inevitable path dependence of institutional transformations. The study of the three sectors of a Southern European periphery, moreover, exposes the role of European institutions in promoting the financialisation of the Portuguese economy, in general, and of key domains of social reproduction, in particular.

Previous work has shown how and to what extent the Portuguese semi-peripheral type of financialisation has been shaped by the process of European integration, which favoured the expansion of loanable capital vis-a-vis that of capital markets (Rodrigues et al. 2016a). ${ }^{6}$ It has also shown that, in the context of the Economic and Monetary Union, sharing a single currency, the expansion of loanable capital has favoured non-tradable sectors, namely the construction and real estate sectors, and fuelled growing household debt, resulting in the extraordinary rise of private debt in the country, a fundamental trait of Portuguese semi-peripheral financialisation when compared with other Southern European countries (Lapavitsas et al. 2012). This paper intends to further elaborate on the semi-peripheral nature of financialisation processes by showing how and to what extent the unprecedented access to bank loanable capital, and the related underdeveloped capital markets, have shaped the ways in which housing, pensions and water systems have evolved in the specific social, political and economic Portuguese context, resulting in different outcomes from those observed in the same sectors in other historical and geographical contexts. It shows that housing has been a most important means to bring households into debt markets through housing loans. Pensions have instead been a most important conduit through which households have increasingly participated in capital markets through the acquisition of life insurance and pension products. And water illustrates the more indirect and potentially unknown ways whereby households become connected with finance through the mere payment of water bills, which are the main source of revenue that pays back debt funded investment in the sector. By transforming the ways in which social provision is organised and delivered in the country, the three Portuguese case studies provide evidence not only for the differentiated but also for the uneven character of the current financialised phase of capitalism, where the subordinated character of Portuguese financialisation has become more evident as well as its uneven impacts. The case studies also bring to the fore the constraints on, and the pressures for, the continued expansion of finance generating ever more uneven impacts.

The paper is organised into five parts. The next section briefly presents the main characteristics of the semi-peripheral financialisation of the Portuguese economy, setting the background for the presentation of the three systems of provision. The subsequent three sections look into housing, pensions and water respectively, identifying the factors that have shaped financialisation of these sectors, and their present circumstances and constraints. The final section concludes the paper by underlining the subordinated and context-specific nature of Portuguese semi-peripheral financialisation where the interests of finance located in the major advanced capitalist countries, and of the national and international institutions under their influence, have been most relevant, and resulting socially and spatially uneven impacts. 


\section{The semi-peripheral financialisation of the Portuguese economy: high levels of external debt and prolonged economic stagnation}

Analysis of the content of the financialisation of the Portuguese economy and society has revealed a substantially different experience of the recent rise and influence of finance from that of the AngloAmerican world, an experience that has been conceptualised as a semi-peripheral type of financialisation (Rodrigues et al. 2016a). ${ }^{7}$ This has been shaped by structural features of the economy and the relatively late 'modernisation' of the financial system in the 1990s, first in the context of the European integration process and, subsequently in that of the construction of the Economic and Monetary Union (EMU).

The notion of semi-peripheral financialisation in the Portuguese context accounts, firstly, for the intermediate position of its economy in the world, specifically the fact that this is an industrialised country increasingly unable to compete with the countries with which it is most closely integrated, susceptible to stagnation and vulnerable to external shocks. Secondly, it refers to the role of the process of European integration in shaping the evolution of the financial sector, resulting in the predominance of bank loanable capital within the strict framework of the Euro. This predominant role of bank loanable capital has shaped recent transformations in the economy and society, through intricate debt relations between international finance and domestic agents, including financial institutions, non-financial firms and households.

It should be noted that the hybrid nature of the economy, combining elements of relatively backward structures with a rapidly modernised financial sector fully articulated with core financial centres, is not unique in the European context. Even if to different degrees, Southern European countries share these structural elements resulting in a predominance of loanable capital from external sources, capital accumulation geared towards domestic non-tradable sectors, rising levels of household debt, and a State overly dependent on foreign funding, which together help explain the more severe impact of the Global Financial Crisis (GFC) in these countries (Orsi and Solari, 2010; Gambarotto and Solari, 2015). However, Southern European countries also differ in many relevant respects, exposing the inevitable contextual specificities of institutional change and resulting outcomes.

With its own colonial past, a belated process of decolonisation occurring in tandem with the democratisation of the country following the 1974 Revolution, there was a very favourable political context for rapid Portuguese integration into the then European Economic Community (EEC), formalised in 1986 (together with Spain). Its laggard position in the European context reinforced the role of European integration in driving financialisation processes in Portugal. In a first stage, integration into the European single market for goods and services implied liberalisation and harmonisation with the different segments and practices in the European banking sector (e.g. ending the distinction between investment and commercial banking, abolishing restrictions on the entry of new agents and aligning prudential requirements for the sector with the 1988 Basel Accords). More recently and crucially, 
participation in the Eurozone brought particular, unprecedented and almost unlimited access to hard currency and bank loanable capital at low interest rates, usually unavailable to countries at similar levels of development (Becker et al. 2010).

The financialisation of the Portuguese economy and society was a rapid, but effective, process of socioeconomic transformation. Within the time-span of a decade, the Portuguese financial system evolved from a State-controlled financial regime to become fully integrated and liberalised, supported by committed insertion in international circuits of finance. Indeed, in the early 1980s, major economic groups and banks were publicly owned. Interest rates were set administratively, and credit was mostly directed towards the needs of the State and of the associated state-owned enterprises in strategic sectors; there were also strict controls on capital flows, and the exchange rate was defined using a sliding scale pegged to a basket of foreign currencies. This configuration, locked-in by a socialist leaning Constitution declaring nationalisations as 'irreversible conquests of the working-class', was antithetical to the wider neoliberal international trends at the time with which Portugal eventually aligned, albeit, as typical in the semi-periphery, with a time lag.

The combination of two IMF interventions (in 1979 and in 1983-85) in addition to preparation for accession to the EEC set a favourable context for what has been uncritically labelled the 'modernisation' of the Portuguese financial system from the mid-1980s onwards. The privatisation and liberalisation of the financial sector, which put an end to credit limits and administered interest rates, were the first set of factors contributing to the increase in bank lending in the 1990s. A second set of factors is linked to the release of (poorly remunerated) compulsory reserves deposited in the Bank of Portugal, which were subsequently transformed into public debt negotiable at market prices, and the gradual rise of securitised public debt, traded on secondary markets and open to foreign investors. The removal of all national controls over the international circulation of capital, reflected in the full convertibility of the escudo, was the culmination of the process of transformation of the financial sector. The changes in the exchange rate policy meant the substitution of the goal of competitiveness with a disinflationary target, in line with the strictures of the European Monetary System and the Exchange Rate Mechanism, which the country joined in the 1990s.

The processes of bank privatisation and financial liberalisation, which were basically completed in the early 1990s, and the nominal convergence trajectory culminating in accession to the Euro - all contributing to the over-appreciation of the escudo - were decisive factors in transforming the Portuguese economy into a financialised one. The remarkable decrease of real interest rates was, then, seen as the most relevant sign of the successful insertion of national finance into international financial markets. From indebtedness levels below the European average in the mid-1990s, Portuguese firms and households were geared to the top in the first decade of the Euro. ${ }^{8}$ 
Despite the speed of these transformations, the transition was smooth without the financial instability that frequently accompanies such processes. ${ }^{9}$ The Portuguese case is even more remarkable when considering the scope and depth of these transformations, considering the very timid engagement with finance in the mid-1990s to skyrocketing levels of private indebtedness when the financial crisis hit in 2008, the main culprit for turning Portugal proportionately into one of the highest externally indebted countries in the world.

The policy of nominal convergence, as part of the construction of the single European currency, ultimately created conditions for future troubles. Portugal entered the Euro with an over-appreciated exchange rate and with an already unbalanced economy. A current account deficit started to mount, since the government could no longer rely on devaluation to boost its exports and solve its balance of trade problems. ${ }^{10}$ The appreciation of the Euro in the 2000s aggravated this problem further. In a context marked by continuing downward pressure on prices, Portuguese firms, mostly price-takers when operating internationally, saw a decrease in their profit margins. Incentives were thus geared towards the profitable non-tradable sectors of the economy, less exposed to foreign competition - from construction to retail and privatised utilities. The banking sector played a pivotal role in these structural transformations, channelling foreign credit, directly or indirectly (i.e. through households), to these sectors. This has meant that the extraordinary inflow of capital, even if at a low cost, did not result in positive structural transformations in the tradable sectors of the economy. On the contrary, a decaying manufacturing sector was progressively replaced by construction and real estate. ${ }^{11}$ High external and unsustainable debt is thus not so much related to the cost of capital per se but largely to the insertion of the non-competitive economy in the international arena and corresponding intertwining with international finance. This translated into prolonged economic stagnation even before the crisis. ${ }^{12}$

This diagnosis is shared. Amaral (2015: 83-4), for example, asserts that during 'the period of preparation for accession to the EMU, between 1990 and 1999, [...] many of the conditions that had allowed previous growth vanished, especially in the domain of exchange and monetary policy', dubbing the first ten years of Portugal's participation in the EMU as 'the lost decade' leading to 'the return of enduring divergence of our economy relative to more developed ones'. ${ }^{13}$ Amaral (2015: 105) then concludes that the recent evolution of the Portuguese economy has been marked by two movements: economic divergence, resulting from the low capital intensity of the economic structure, on the one hand, and 'the almost complete convergence in political and institutional terms', stemming from its European integration. Similarly, Louçã (2011: 79) asserts that the Portuguese economy has turned into a 'bipolar economy': 'backward in its system of production, modern in its system of consumption, backward in its system of social protection, modern in the expectation of life improvement it generated'.

This analysis contrasts with those that focus on fiscal and domestic factors, attributing the source of the Portuguese troubles to a lack of fiscal discipline (e.g. Braga de Macedo 2003; Torres 2009; Royo 2010, 
2013). For example, Royo (2013: 207) asserts that the poor economic performance of the country is due to the failure of European institutions (e.g. the Stability and Growth Path) 'to force the necessary reforms to address Portugal's historical problems of fiscal mismanagement', and the protection provided by participation in the Eurozone 'by shielding the country against attacks'. But Royo underlines that this problem does not concern the European institutions, but instead national political actors because, in his view, 'the process of economic reform has to be a domestic process led by domestic actors willing to carry it out' (ibid). However, rather than an issue of lack of fiscal discipline, we argue, the major source of troubles for the Portuguese economy lies in an over-appreciated currency and the lack of monetary and exchange policy instruments to deal with it. ${ }^{14}$

The structural characteristics of the economies (instead of their moral and cultural attributes) are also most critical to account for the differentiated and divergent paths of core and peripheral countries, as well as variation within the Southern European periphery. As Gambarotto and Solari (2015: 789) put it 'the interpretation of the euro troubles as a problem arising from fiscal alignment or from a lack of fiscal discipline provides only a partial and institution-free view of the European economies'. Drawing on the Varieties of Capitalism literature, Gambarotto and Solari argue that core countries such as Germany, the Netherlands, and the UK (export-oriented and with more developed capital markets), must be differentiated from peripheral countries such as Italy, Greece, Spain, and Portugal (with import-oriented economies centred on the domestic market, following deindustrialization processes after the Euro, and finance expansion based on credit). These differences not only help understand the divergent paths since the implementation of the Euro, but also the differentiated impacts of the GFC with its significantly harsher effects on Southern European economies. For example, supply-side policies proposed to cope with the crisis, such as labour-market flexibilisation and business liberalisation, are deemed to have worsened the situation of these countries by downgrading their patterns of specialisation, resulting in a reduced increase in productivity. A different conclusion then emerges than that based on fiscal imbalances: 'the European political process of unification left peripheral countries [...] exposed to external pressure on the sectors of their production specialization', particularly hitting Portugal and Italy (Gambarotto and Solari 2015: 804). Besides subordination and variegation between and across European core and peripheral countries and within the periphery, variegation is present within each country and this is the point to which we now turn.

\section{Financialised housing: empty, inaccessible homes and foreign investment}

The expansion of bank loanable capital has had a tremendous impact on the Portuguese system of housing provision. It absorbed a great part of loans granted to business and households as real estate lending has gone into the production of dwellings as well as their purchase. ${ }^{15}$

These transformations were also encouraged by EU banking regulations that favoured the financing of homeownership through mortgages (considered the most secure form of credit since they are based on 
a durable asset as collateral), and the upstream activities of construction and real estate (Allen 2004; Aalbers 2008). Continued public investment in infrastructure further favoured these sectors. Even if the Maastricht fiscal criteria and the Stability Pact constrained public investment, various financial engineering arrangements, such as the creation of State-owned enterprises or Public Private Partnerships, allowed for disguising public expenditure in infrastructure. Lax land regulation, associated with incentives for local municipalities to approve construction, also favoured the construction boom in the country (Santos et al. 2015). ${ }^{16,17}$

Reflecting the move of domestic capital to sectors relatively insulated from international competition, the construction of household dwellings rose dramatically, with the number of completed dwellings in new constructions for family housing doubling from 1995 to $2002 .{ }^{18}$ However, this construction boom meant a dysfunctional use of land and an oversupply of dwellings, with an extraordinary proportion of vacant housing units. ${ }^{19}$

The traditional weakness of the Portuguese Welfare State, conceding only a marginal role to social housing (representing 3\% of total housing stock of permanent homes in 2011, Matos 2012), and a housing policy focused on the promotion of private ownership (Serra 2002), together help explain the extraordinary rise in housing loans. Already prior to membership of the EEC, ownership rates were high in EU terms. But the financialisation of the Portuguese economy ultimately provided the conditions for the success of a policy model based on homeownership through the use of credit. ${ }^{20}$ The role of the central government in this process is evident. Between 1987 and 2011, 73\% of the government budget devoted to housing was spent on subsidies associated with loans for permanent homeownership, $14 \%$ was used on rehousing programmes, $8 \%$ was used on rent subsidies, and only $2 \%$ was spent on direct promotion of housing (IHRU 2015a). State support was thus relevant to ensure that mortgage-led demand for new homes grew in tandem with the rise in the housing supply. Thus, the housing system of provision has accounted for a large portion of households' financial activities through mortgage markets, as a result of unprecedented access by the Portuguese banking sector to European credit markets, and the specificities of the Portuguese housing system of provision that was by and large dominated by private and commodified forms of provision.

At the turn of the millennium, housing oversupply and the end of State support for mortgage credit resulted in a slow burn crisis in the domestic construction sector, with very asymmetrical social and regional impacts. ${ }^{21}$ The 2008-2009 crisis accentuated the sector's imbalances, with the decline in disposable household income and the rise of unemployment rates leading to the rise of credit arrears, even if default rates of mortgage loans remained at relatively low levels (approx. 3\% in 2015). ${ }^{22}$ All this has represented an important constraint on the continued expansion of finance in the housing sector from a demand side viewpoint. 
Another type of constraint emerged from the concentration of mortgage debt in higher-income households. In Portugal, as elsewhere, mortgage markets have been a privilege of the middle to upper classes, who have had access to this type of loan because they have enough wealth for a deposit and collateral, having almost exclusively benefited from cheap subsidised credit (Santos et al. 2015). ${ }^{23}$ The extraordinary expansion of household debt should thus be understood as the easiest and cheapest way for the wealthier households to gain access to housing. Departing from very low debt levels, the rise of indebtedness was not only generally sustainable in respect of a household's ability to pay, but was also a relatively safe way to accumulate wealth, despite the drop in housing prices in recent years. With most of these mortgages contracted at variable rates indexed to the interbank rate Euribor, monthly repayment amounts have followed the decline of ECB interest rates since 2009, allowing for a significant reduction in levels of mortgage loan repayments, in contrast to the general rise of rents due to the liberalisation of the rental market. Low-income households, excluded from homeownership and social housing, have faced increasingly higher housing costs, resulting in the escalation of inequalities in access to housing. ${ }^{24}$

Since 2008 mortgage markets have slowed down and access has become more exclusive, with borrowers expected to put down larger deposits, and lenders seeking more stringent evidence of ability to make repayments, including close scrutiny of the income, and even the spending habits, of prospective borrowers. All this has served to increase mortgage market segmentation. The current economic situation, marked by stagnation, high levels of unemployment among the young, precarious labour relations and low wage income, have further contributed to skewing mortgage markets towards the welloff (Costa 2016), accentuating its inequality-inducing effects, providing further evidence for the exhaustion of a model based on financialised private provision of housing. Public debt reaching record highs, a shaky banking sector requiring constant assistance from public authorities, and an impoverished middle-class, together dictate the end of a housing policy based on loans for homeownership. Under the new circumstances, house rental has become the main alternative for both families looking for a home and for promoters who need to sell their properties.

The dysfunctions of the Portuguese housing system are acknowledged by public authorities. The public institute responsible for implementing housing policy in Portugal, the Instituto da Habitação e da Reabilitação Urbana (Institute for Housing and Urban Rehabilitation), has noted the paradoxical situation of the Portuguese housing sector, with the co-existence '[o]n the one hand [of a] high number of empty homes, [and] on the other difficulties experienced by families in finding housing that is adequate to their means and needs' (IHRU 2015b: 6). It also acknowledges that the housing problem in Portugal results from the '[t]he politics of promoting and financing the acquisition of private housing', which 'ended up having a perverse effect in price increases and contributed to the accumulation of very high levels of debt by the State, the banking sector, companies and households'. The overall assessment of a public policy devoted to the promotion of homeownerships is that '[r]elated public and private investment ... neither contributed nor enabled familial access to housing'. These policies instead 
promoted 'the expansion of urban peripheries, in many cases segregated and in poor conditions, $[\ldots]$ added home-to-work commutes and exponentially increased energy consumption for transport. In the case of historic centres, these policies increased local costs, promoting only very costly building rehabilitation projects' (p. 11).

In the present low interest rate environment, real estate has also become a more attractive destination for idle domestic and foreign capital. Policies conducted to deal with the financial crisis, namely the large scale programme of quantitative easing carried out by the ECB to ensure that interest rates remained at very low levels, has had the effect of reducing yields on government bonds, bank deposits and pension annuities, raising the relative attractiveness of investment in housing, and in residential lettings in particular (Kemp 2015). Many capital cities have since received a substantial amount of foreign investment from wealthy individuals and institutional investors, such as pension funds and insurance companies, reflecting the role of housing as a 'safe deposit box' under continuing financial turbulence and political uncertainties and turmoil in many parts of the world (Fernandez et al. 2016). That is, the GFC has rendered urban and tourist areas a more attractive destination for investment, contributing to the escalation of housing prices in those areas, further pushing the transmutation of housing into a financial asset, creating new forms of economic, social and territorial disruption. This is visible in the two major urban centres of the country, Lisbon and Porto, and also in the country's traditional tourist region of the Algarve. ${ }^{25}$

This provides yet one more illustration of how external factors are combined with particular national and local interests, where central and local governments are not merely passive agents. Under a stagnated domestic market, both central and local government have actively promoted foreign investment in real estate, for example facilitating residency permits in exchange for the purchase of expensive properties (i.e. Golden Visas), or by conceding important fiscal incentives to foreign investment, namely reductions or temporary exemptions from municipal tax.

The qualitative transformation produced by the gradual substitution of domestic ownership by foreign investment in real estate is thus another consequence of financialised housing with potentially dramatic social, territorial and economic impacts. Some of these are already visible in Lisbon, with landlords increasingly substituting long-term tenancies for locals with short-term rentals for tourists, gradually expelling the former from the city centre, as they can no longer find affordable rents. ${ }^{26}$ This is bringing about radical transformations in the city, replacing an already highly pressured residential area by hotels, hostels, restaurants, bars, shops and other tourist-related services.

To summarise, the financialisation of housing has accentuated severe dysfunctions in Portuguese housing provision, including the coexistence of oversupply and shortage of homes, a highly segmented mortgage market, an insufficient rental market, marginal non-commodified forms of housing provision, economic decay in rural areas, and intense pressure on big urban centres. These dysfunctions constitute 
obstacles to the continued expansion of finance based on bank loans to households, being redirected to more segmented, profitable connected markets rather than towards productive investment.

\section{Financialised pensions: insufficient retirement income and foreign financial institutions}

While housing has been the preferred conduit through which (a segmented part of) households have increasingly participated in debt markets, pensions have been increasingly responsible for household participation in capital markets in EU countries (Santos and Teles 2016). ${ }^{27}$ Portugal is no exception. However, household involvement with finance has been mainly dominated by financial liabilities rather than financial assets, a difference that is partly explained by the intermediate position of the country, and by the specificities of the Portuguese housing and pensions systems of provision. While housing provision has been the almost exclusive domain of the private sector, even if at times substantially supported by the State, as we have seen, pension provision is mainly public and based on the pay-asyou-go principle, with a still limited presence of private-funded pension schemes, which are the archetype of financialisation within this realm of social provision. ${ }^{28}$

The Portuguese social security system was formally established in 1984, betraying the late institutionalisation of a social protection system in the country and going against the neoliberal trends emerging at the time at the international level, and also in other domestic areas (Mendes and Albuquerque 2014). The public old-age pension system, in particular, is an obligatory protection system based on a pay-as-you-go rationale with defined benefits. This means that current pension payments are financed by contributions from workers and employers in the contributory scheme, and by transfers from the State budget in the non-contributory scheme. The system thus functions on the basis of intraand inter-generational social solidarity.

This belated construction of the Portuguese social protection system has represented a slow maturation and convergence with the EU, in line with other countries in Southern Europe, with spending on social security rising from 7.3\% of GDP in 1986 (the year Portugal joined the EEC) to $12.3 \%$ on the eve of the financial crisis in 2007. ${ }^{29}$ The number of old age pensioners in Portugal, about half a million in 1975, tripled in 2000 and quadrupled in 2013, surpassing 2 million beneficiaries. ${ }^{30}$ This evolution is in part due to the inclusion of a growing number of workers in the universal public system, but, above all, to demographic trends associated with an ageing population. It is therefore not surprising that spending on old age pensions, which in 1975 amounted to $1.2 \%$ of GDP, rose to $3 \%$ in 1991, reaching $6 \%$ in $2013 .{ }^{31}$

However, the average value of pensions has remained low, reflecting the country's low wage level. In the early 1990s, over $90 \%$ of elderly people were receiving pensions that were lower than the national minimum wage. Due to economic development and longer working lives associated with higher wages and contributions, new pensioners began to retire with increasingly higher pensions. Even so, in 2013, $78 \%$ of pensioners were receiving pensions that were lower than the minimum wage, indicating persistently low pensions. ${ }^{32}$ 
Notwithstanding the low level of pensions and the existence, until very recently, of a surplus of contributions in relation to spending on contributory schemes, ${ }^{33}$ the system is seen as being threatened by demographic trends. European integration has contributed to this perception with European institutions increasingly stressing the imperative of balanced public finances (EC 2006), once again reinforcing the subordinate position of the country at the sectoral level.

Indeed, the public pension system has been subject to revisions over time. In 1993, these included the gradual rise in the retirement age for women to equality with that of men, the extension of the eligibility period (from 10 to 15 contribution years) for accessing old age pensions, and the extension of the contribution period used to calculate pensions (from the best 10 years to the final 15 years). In $2000 \mathrm{a}$ new Framework Law on Social Security enshrined the principle that the calculation of pensions should consider all contributions rather than those made in the last fifteen years, which was later established by a Decree-Law in 2002 that included a transition period from 2002 to 2016. This was a highly important 'parametric' change designed to reduce the value of pensions and it marked the beginning of the new millennium as a moment of change in the rationale of the system, one that aimed at tying pensions more closely to earnings from individuals' working life, implying further removing them from current incomes in society at the point of retirement.

Based on strictly financial criteria aligned with European priorities for public finance, and European institutions' diagnoses and recommendations for pension provision within the so-called Open Method of Coordination, a form of European soft power, the 2007 Framework Law introduced new changes into the formula for calculating pensions, which imply further reductions. These included: the introduction of a 'sustainability factor' that takes into account increased life expectancy; anticipation of the adoption of the whole contribution period; and de-indexation of pensions to the minimum wage by creating a 'Social Support Index', which only guaranteed the purchasing power of the lowest pensions (Rodrigues et al. 2016b). ${ }^{34}$

Based on the 2007 reform, the European Commission (2012) predicts that Portugal is one of the EU countries in which spending on pensions will increase least between 2010 and 2060 (0.2\%), allowing for placing pensions, as a percentage of GDP, in line with the average by 2060 . Naturally, this implies a clear sacrifice in pensioners' standard of living since it is associated with a sharp decline in the replacement rate of pensions from almost $90 \%$ to $53 \%$, becoming one of the lowest in the EU, producing growing inequality between the incomes of pensioners dependent on public provision and the rest of society (Mendes 2011). This signals the transformation of pensions into one of the adjustment variables in the economy, which has become accentuated with the economic crisis from 2008 onwards and the harsh austerity measures included in the framework of the Memorandum signed with the Troika in 2011 that specifically targeted pensioners' income. 
These changes, together with a permanent legitimising discourse focusing on the impending structural threat to pensions, are fuelling a growing mistrust of the public system. An opportunity has therefore been created for the private schemes to prosper amongst the wealthier and more politically influential sectors of Portuguese society.

Given the tardy set up and the time taken to consolidate the social security system, the emergence of private forms of provisioning retirement income, through pension funds and life insurance, is first and foremost an outcome of developments within the financial sector itself. They were first created in 1985, at the time being restricted to funds managed by insurance companies soon to be extended, in 1986, to pension fund management companies. In 1989 pension savings plans (PPRs, Planos de Poupança Reforma) and retirement savings funds appeared, promoted by the State via income and capital tax breaks. Although the initial growth was spectacular - 149 pension fund management companies were created between 1987 and 1988 - the regulatory limits placed on their management were very restrictive at the time, for example requiring funds to hold at least $50 \%$ of their assets in public sector debt securities (Pedras 2000).

The pension funds sector grew in the 1990s, by and large driven by the privatisation of large companies and, above all, of banks that created their own pension funds, the latter holding $57 \%$ of all pension fund assets in 1998. The overwhelming majority of these private pension schemes consisted of defined benefit funds resulting from collective agreements with workers which aimed to replicate the rationale of the pay-as-you-go social security system, although they were different in nature since they involved funded schemes and hence were dependent on financial markets. Pension funds grew exponentially in the decade, reaching around 12\% of GDP in 1998 (Pedras 2000).

In the new millennium these funds declined, with a sharp fall after 2010, reaching 10\% of GDP in 2013. This fall is primarily explained by the transfer of funds from the banking sector to social security. In a context of stagnation, the crisis in the capital markets and the reduction in the number of workers in the sector, banks transferred their future (defined benefits) employee responsibilities to the State, providing the latter with short-term financial assets that enabled the reduction of the fiscal deficit. This very tellingly revealed the failure of a private, defined benefits capitalisation model whose associated future costs rendered it unattractive to the Portuguese banking sector. Nevertheless, some banks still remain the main holders of pension funds, largely replicating the current oligopoly in the Portuguese banking market (ISP 2013).

In addition to pension funds, there was also a marked growth in PPRs offered by insurance companies. Unlike the aforementioned pension funds, the PPRs do not provide defined benefits; they offer instead the capitalised value of the financial application at retirement, actually being low-risk profile investment funds. The value of the PPRs has increased exponentially from 2 to 12 billion Euros between 1998 and 2013, an evolution that in its early stages was actively promoted by the State through significant 
concessions in the form of tax exemption for individual investors, contributing as well to their implicit returns (ISP 2010, 2013).

Despite claims that they are an efficient mechanism for mobilising and allocating capital, the growth of PPRs has resulted in a remarkable channelling of capital out of the country, particularly to other EU countries. ${ }^{35}$ Although this may be explained by the narrowness of the capital markets in a semiperipheral economy such as the Portuguese, the negative effect on the Portuguese economy is undeniable, since these investments represent a transfer of financial resources to outside the country. Moreover, in contributing towards lower economic growth, lower employment and fewer contributions to the social security system, they ultimately have a detrimental impact on the sustainability of this system. The GFC has exposed the fragility of pension funds and the reliance on capital markets even further, as a result of the recent drop in interest rates to near zero values and prolonged international economic stagnation, producing high volatility that further pushed down returns in equity markets compromising pension product yields (Casey 2012).

Finally, it should be noted that the Social Security System has not been immune to the idea of capitalisation. The Social Security Financial Stabilisation Fund (Fundo de Estabilização Financeira da Segurança Social, FEFSS), created in 1989 with an initial allocation of 216 million Euros, illustrates this well. The FEFSS has sought to copy the investment strategy of private funds, whose resources originate from contributions from salaried workers. The portfolio of this fund has expanded steadily over the past twenty years, totalling 7.1\% of GDP in 2013. However, the investment rules for this fund are considerably more restrictive than those applied to private funds, requiring a minimum investment in Portuguese State debt (IGFCSS 2014).

Similar to the prospects for financialised housing in the aftermath of the GFC, the current economic situation, marked by stagnation and a gloomy outlook resulting from a high level of State debt to be paid off over the next two decades, the high levels of youth unemployment, precarious labour relations and low wage income, hinder the expansion of finance in this realm of social provision.

To summarise, the construction and subsequent erosion of the State pension system has been accompanied by the slow growth of private pension schemes. Portugal thus occupies a modest position in terms of the importance of life insurance and pension funds in relation to wealth generated. This is partly explained by the late development of the State pension system and against the neoliberal influence at the time, as well as the semi-peripheral nature of the country with a relatively immature capital market and low levels of disposable household income. In the aftermath of the GFC there is little room for channelling almost non-existent savings to capital markets while the State is financially drained and unable to sponsor such schemes on a large scale. Financial institutions, particularly insurance companies, nowadays belonging to foreign capital, capture a small and lucrative market, which has become yet another mechanism for exporting capital to the EU core. Similar to housing, and exposing 
the semi-peripheral condition of the country, the expansion of finance in pension provision faces severe obstacles pointing towards a different and more limited form of financial expansion, increasingly involving foreign financial institutions and targeting an ever more segmented market. Only the wealthier will be able to complement retirement income through private means. But even they will find it difficult to secure living standards equivalent to those previously offered by the public system. Increasing segments of the retired population will face a substantial reduction in their living standards with the reinforcement of the link between contributions made during working life and future pensions, within the current and foreseeable economic situation. This will also be detrimental to the pensions provided by private-funded pension schemes because they too depend on returns from the capital invested and thus on economic performance.

\section{Financialised water provision: debt, rising bills and selective foreign investment}

The recent evolution of water provision is also shaped by the semi-peripheral condition of Portuguese financialisation that allowed easy access to foreign capital loans. In the 1980s, the sector benefitted from considerable public investment in the improvement of what were then judged as highly deficient water and waste systems. But the most significant transformations in the sector occurred in the 1990s when it was reorganised. Based on the diagnosis of investment needed to upgrade the different water provision systems, large capital loans were required from external sources, and following EU guidelines for the sector, three major institutional transformations were introduced: the corporatisation of the public sector; the introduction of market-oriented practices in water management; and the entry of private capital investment (Pato 2011). ${ }^{36}$

Corporatisation of the public sector involved the deverticalisation of water provision systems, separating the (capital-intensive) bulk sector (catchment, treatment and storage of water) and the retail sector (storage and final distribution). The bulk sector was regionally integrated into 19 multi-municipal companies with municipalities keeping a $49 \%$ share. Control of the sector was transferred to the newlycreated public holding Águas de Portugal (AdP) that retained a 51\% share in each of these new companies. Corporatisation of the sector, through the creation of these new public companies, was understood as a way to enhance efficiency, since professional management was considered to be less permeable to political pressures than public management directly subjected to political power. Moreover, the introduction of the corporate management model was also motivated by the need for convergence with European rules to meet the conditions for accessing investment subsidies from the EEC and loans from the European Investment Bank (Teles 2015).

Given the municipal control of water provision, the transfer of power to AdP had to be agreed voluntarily by municipalities. Lured by the promise of new investment in the capital-intensive bulk sector, without incurring further costs, most municipalities accepted this new architecture. Today, these companies cover around $71 \%$ and $67 \%$ of the population in bulk water supply and in bulk wastewater management 
respectively. Municipalities that refused at the time to participate in this process cover the rest of the population (ERSAR 2012).

The retail sector remained in the hands of local municipalities, which held the power to fix and charge tariffs for domestic users. But it did not escape the move to corporatisation. Various municipal companies were thus created with the single purpose of managing retail provision of water and wastewater treatment. While most of these companies retained public ownership, being owned by the local municipality, several municipal companies were created in partnership with private capital, which hold a minority share. These partnerships led to the gradual involvement of construction companies, which in many cases benefitted from contracts with the municipal companies. But the most significant change at the retail level, since 1993, was the entry of private capital through Public Private Partnerships (PPPs) in municipal concessions. Coinciding with the expansion of water multinationals in other locations, a small number of municipalities covering large populations ceded their retail systems to multinational companies, such as Veolia, for extended periods. Again, the expectation was that this would allow new investment financed from sources other than municipal budgets.

The introduction of market-oriented management practices in the provision of water was enforced through the creation of a regulatory agency for the sector. First established in 1995 as the Supervisory Commission for Concessions, the scope of the regulatory agency has expanded, becoming, in 2009, the Water and Waste Services Regulation Authority (ERSAR), the regulation authority for the entire water and waste sector. As a regulatory body, ERSAR's mandate currently rests on the principle that a natural monopoly ought to be regulated to ensure the adequate protection of consumers. But it is also deeply concerned with the elusive goal of market efficiency. While endorsing as its mission 'to ensure adequate protection of consumers $[\ldots]$ by promoting the quality of the service provided by the operators and guaranteeing socially acceptable pricing', at the same time it stresses the need to safeguard 'the financial viability and best interests of the operators, irrespective of their status' (ERSAR 2012: 17). This concern is explicitly conveyed in its endorsement of the total cost recovery principle in calculating the prices of water and wastewater services, and the recommended targets for the return on capital on these investments of about $5-10 \%{ }^{37}$

The massive entry of private capital was another hallmark of the evolution of the sector in the 1990s. European grants and abundant foreign credit available (from the European Investment Bank, domestic banks and foreign bond markets) funded massive investment in the water and wastewater systems. Coverage of water supply and wastewater improved considerably, particularly in treated wastewater, with coverage rising from $25 \%$ in the mid-1990s to $75 \%$ at the end of the 2000 s. The expansion of coverage was followed by an impressive improvement in the quality of water supply, and also significant progress in the treatment of river basins and coastal waters (Teles 2015). 
With the State constrained by the EU Stability Pact's deficit limits, the scale of investments was only made possible with EU transfers and recourse to (mainly foreign) credit, to which Portuguese agents had privileged access from the early 1990s until the 2011 Eurozone crisis, as mentioned above. Thus, the recent evolution of the water sector was also by and large determined by participation in the EMU that allowed the Portuguese economy to benefit from new and unconstrained access to capital at historically low interest rates in international (European) markets. The country's semi-peripheral position, with its over-appreciated real exchange rate within the Eurozone, was beneficial to the agents operating in the water and connected sectors, including construction companies, which were relatively more protected from external competitors.

AdP, with its corporate structure, was of pivotal importance, channelling most of its external funding to the companies that it controls and that operate in bulk water supply and wastewater sectors. The scale of AdP enabled it to acquire financial know-how in domestic and foreign financial markets, having had access to three different funding sources: European subsidies, long-term debt (mainly coming from the European Investment Bank (EIB) and bond issuance), and short-term loans from the banking sector. The bulk of this debt consisted of EIB loans with long maturities and low interest rates, whose relative importance as a funding source rose from the early 2000s. Private banking debt, accounting for about $20 \%$ of total debt in 2013, regards loans both from major foreign banks, such as Deutsche Bank and DEXIA, and domestic ones, such as BPI. AdP also resorted to bond markets, issuing bonds to a very small number of foreign investors during the 2000s in order to match their long-term investment with long-term debt. The success of these bond market operations was attested by the low interest rates charged (amounting to $1.8 \%$ in 2013), showing both the scale achieved by AdP as a company and its deep involvement with international finance. Finally, the financial sophistication of AdP and its financialised profile is also clearly attested by its portfolio of swap derivatives, most of which aimed to protect against interest rate volatility (AdP 2014).

The scale of much needed investment helps understand why such far-reaching institutional transformations did not face much popular resistance during the 1990s and early 2000s. These transformations coincided with extraordinary progress in the provision of water and wastewater and the relatively contained growth of tariffs set by the municipalities. Nonetheless, the increasing role of finance in water provision - through debt that funded most of the new investment - set the scene for a new stage where the relation between finance and domestic consumers became increasingly tightened. Rising financial costs associated with rising debt ultimately legitimised enhanced regulatory powers to enforce the cost recovery principle, which has meant the streaming of income from households to finance through water bills, which have risen considerably and above inflation in the past decade despite control over the setting of water tariffs on the part of municipalities and their resistance to adopting costrecovery prices (Teles 2015). The financial conditionality imposed by official foreign lenders (the IMF and the EU) is pivotal in these developments, having actively pushed for the adoption of the full cost- 
recovery principle. This favoured the recent endowment of the regulator ERSAR with legal powers to impose the principle on municipalities (Decree-law n ${ }^{\circ} 10 / 2014$ ).

The public holding company AdP, even if still formally publicly owned, by gradually integrating corporate interests and financial criteria in its management practices, has become increasingly more suitable for privatisation. This may take different forms, including private capital buying a part of the company or, more probably, the expansion of retail concessions to private agents. In whichever case, as has occurred elsewhere, private capital will target the more mature systems where the need for new investment is smaller and tariffs predictably higher, conforming to the practice of 'cherry-picking' (Bakker 2013).

With Portuguese firms among the most indebted in the world and with reduced access to international debt markets, new privatisation waves will most likely involve foreign players. The growing influence of private interests in water utilities is, therefore, likely to continue, contingent on the ability to ensure a predictably stable stream of income that the Portuguese water sector is able to guarantee stemming from the provision of an essential but ever more expensive good.

Similar to the housing and pensions case studies, the recent evolution of the water sector exposes the semi-peripheral position of the country. The growing weight of finance in water provision was by and large favoured by the insertion of the country in the EU, which facilitated access to structural funding, EIB loans, and loans from other European banks. The high indebtedness of the country and of the water sector made them both more vulnerable to the international economic and financial crisis. As a result, new opportunities have arisen for a new wave of private foreign capital entry, where financial agents have already started to participate as stakeholders, further promoting the concentration and fluidity of capital. Thus, in contrast to housing and pensions, which are more dependent on the evolution of disposable household income, the financial and economic constraints stemming from the GFC have created favourable conditions to deepen the financialised character of the Portuguese water sector through involvement of foreign agents in the provision of an essential good. This may include institutional financial investors, implying deepening the connection of households to the world's financial centres, a connection that will be made through the paying of water bills, uniting local consumers with global finance.

Comparatively, the Portuguese water system of provision stands in an intermediate position in terms of the presence of finance in the sector, with the English and the Welsh cases serving as exemplars of most financialised systems in the EU context (Bayliss 2014). The Portuguese water sector has evolved along the same broad lines, even if with a time lag, as those of England and Wales. While corporatisation began in the 1970s and privatisation in the 1980s in those countries, in Portugal corporatisation and privatisation has been partially carried only from the 1990s onwards. However, in England and Wales financialisation was mainly achieved through the capture of cash flows that enabled the leveraging of 
financial vehicles now controlling water provision. Thus, particular, well-identified trends in most financialised countries cannot be taken as common trajectories that less-financialised countries will eventually follow. The Systems of Provision approach stresses that the permeability to finance is not only commodity-specific, requiring linking consumption to chains of production, but also that it is shaped by many various social, political, economic, geographic and historical factors (Bayliss et al. 2013). Indeed, a distinctive feature of the Portuguese case is the municipal control of water provision, which has acted as a force of resistance to further the financialisation of the sector. And, as we have seen, in Portugal the financialisation of the water sector is intrinsically associated with the process of European integration, and more recently, with participation in the Eurozone, which enabled access to European financial inflows, mainly in the form of debt.

To conclude, finance has been crucial to the evolution of the water sector in Portugal, first through rising levels of (foreign) debt and, at a later stage, through the use of more sophisticated instruments (e.g. PPPs, private concessions) and with the intermediation of new agents (e.g. foreign multinationals and new financial agents). Significant changes are still under way, intensifying the corporatisation of the sector, private enterprise management practices through cost recovery tariffs and the entry of private capital. However, reflecting the more peripheral position of the Portuguese economy and of its financial system, the relatively weaker role of capital markets means that a full convergence of the Portuguese water system to the financialised models in countries with well-developed financial markets, such as the UK, is highly unlikely. The Portuguese water system still exhibits a relatively small reliance on sophisticated financial instruments and water and waste water tariffs are still determined on grounds other than those based on strict financial market-based criteria.

\section{Subordinated and variegated financialisation producing inequality and unevenness on the periphery}

The Portuguese semi-peripheral type of financialisation has been shaped by the process of European integration, which favoured the expansion of loanable capital. In the context of the Economic and Monetary Union, the expansion of loanable capital favoured non-tradable sectors and fuelled growing household debt, resulting in the extraordinary rise of private debt in the country, a fundamental trait of Portuguese semi-peripheral financialisation when compared with other Southern European countries. The housing, pensions and water Portuguese case studies expose the subordinated and variegated nature of the contents and impacts of financialisation on a semi-peripheral country that has followed similar and distinct processes to those of most financialised core countries. They illustrate, at the sectoral level, the two twin movements that have characterised the recent evolution of the Portuguese economy: socioeconomic divergence in tandem with political and institutional convergence. The case studies also show how these movements have accentuated after the Global Financial Crisis as a result of the continued expansion of finance, creating more inequality and unevenness. Taken together, they lend 
support to the analytical value of comparative exercises, which not only help uncovering the divergent paths of EU countries following the implementation of the Euro, but also the differentiated impacts of the GFC due to hierarchical and unequal power relations and the inevitable institutional pathdependence of socioeconomic processes and outcomes. And they show that fiscal discipline alone do not account for either divergent or convergent paths, much less explain the variegated manifestations of those paths at the macro, meso and micro levels.

Given its semi-peripheral position, the analysis of Portuguese financialisation brings to the fore the highly hierarchical and unequal power relations of global finance. Even if articulated with particular national interests, through the process of European integration Portugal was compelled to join an increasingly financialised world economy, serving, primarily though not exclusively, the interests of finance located in the major advanced capitalist countries. Increasingly integrated within a highly hierarchical and unequal financial system, the result was the exponential growth of private debt and ultimately a sovereign debt crisis when the State could no longer finance itself on international markets. The result has been a most severe economic and financial crisis, compromising both financial and nonfinancial national interests, and favouring the entry of foreign capital into the country.

As in other EU countries, finance has expanded considerably in various domains of economic and social provisioning and infrastructure. The financial sector has undergone what has been labelled a process of modernisation associated with privatisation, liberalisation and reregulation processes favourable to the expansion of financial interests. The most remarkable feature of the financialisation of the Portuguese economy and society is the rise in private (in the case of housing) and public (in the case of water) debt.

As financialisation processes interact with others in the context of specific economies, shared trends have different contents and impacts, even within semi-peripheries. The three case studies illustrate well both the systemic and the context-specific aspects of financialisation. The domination of a neoliberal agenda is present in the three sectors through the expansion of markets and commodified forms of provision, including the promotion of credit as the privileged form of producing and accessing increasingly privatised and commodified goods (as in housing), the promotion of private commodified alternatives in tandem with decreased provision of non-commodified public goods and services (as in pensions), or through the corporatisation of public entities ever more amenable to privatisation (as in water).

The three case studies also illustrate well the context-specific nature of each of the three systems of provision analysed, bringing to the fore the nature of the goods or services provided. As the most commodified system under analysis, housing most closely followed the evolution observed in most financialised countries, resulting in the rise of empty homes, on the one hand, and shortage of homes in the city centres of major urban areas, on the other, with more difficult access to housing due to house price inflation. Signalling its full integration in an increasingly financial and politically unstable world, 
the real estate of its capital, Lisbon, has also become an apparently profitable 'safe deposit box' for foreign wealth. As the least commodified system, pensions are still in the domain of the State, with a relatively small and highly segmented private pension market. However, the growth of private pensions has legitimated the decline in coverage and benefit of public pensions without achieving an equivalent match in supplementary private forms of pension provision, which nonetheless imply an important outflow of capital. While still in the hands of public entities, the recent corporatisation of the water sector has made it more attractive to private and financial interests, with imminent new waves of privatisation associated with the entry of foreign capital in the country. Notwithstanding their relative intermediate levels of financialisation, the case studies also show that their context-specific elements prevent taking most financialised Anglo-American systems of provision as endpoints of a continuum to which other systems will eventually converge. Finally, they show that financialisation processes reproduce and create new inequalities, resulting in the rise of social and spatial inequalities, which are not felt the same way by all classes, social groups or locations: homeowners $\mathrm{v}$ tenants, young $\mathrm{v}$ older workers, coastal urban v rural mainland parts of the country, centres v peripheries. Thus, the Portuguese case also shows the extent to which peripheries are privileged vantage points from which to expose the inequalities and unevenness produced by financialised capitalism, supporting the pursuit of further studies on financialisation in the periphery and semi-periphery.

But from this it certainly does not follow that we are on the verge of a reversal of neoliberal policies that have produced social and spatial unevenness. The case studies also illustrate well the plasticity of finance and how it is able to bypass context-specific hurdles (e.g. the lack of financial viability of certain investments that remain in the hands of the State), and how its influence may be exercised through more direct or indirect ways (e.g. attractive favourable tax treatment for foreign investment), being able to penetrate different institutional realities, private and public, through the prerogative of capital to impose its own standards. In so doing, the case studies demonstrate not only the analytical value of extending financialisation studies to the periphery, exposing the subordinated nature of its processes and outcomes, but also the analytical value of including in the analysis domains of social provisioning and infrastructure that add commodity-specific layers of variegation, revealing the plasticity of finance to adapt to national-sector-specific conditions.

Indeed, this plasticity is what explains, despite the severity of the GFC crisis in this semi-peripheral country, the ongoing pressures for the continued expansion of finance. While the prospects for finance expansion are now more limited for the indebted domestic agents with more difficulty in accessing loans, new opportunities arise for foreign actors in particular markets, entailing a more relevant role for foreign capital markets in the future. Thus, we anticipate a qualitative change in the future of financialisation in Portugal, one less extensive in scope but more intensive in form and content, strengthening the power of domestic and financial elites and their hold over State policy. 
Reversing the inequality and unevenness thereby created imply the de-financialisation of the economy and society. But this must avoid a one-size-fits-all recommendation, such as the promotion of patient (commercial) "bank-based" finance rather than (investment banking) "market-based" finance. Repositioning the role and power of finance in the economy to better serve societal needs requires instead a tailored-made policy agenda, and one that includes both a national strategy for promoting greater autonomy of domestic finance from the international financial arena, and a sectoral approach that helps accomplishing this autonomy through renovated relations between finance and the rest of the economy. However, this is a challenge that goes well beyond the scope of this paper.

\section{References}

Aalbers, M.B. (2008), 'The Financialization of Home and the Mortgage Market Crisis', Competition \& Change, 12 (2), pp. 148-66.

Águas de Portugal [AdP] (2014), Relatório e Contas [Annual Report] (Lisbon: Águas de Portugal). Available from: http://www.adp.pt/en/adp-group/financial-information/annual-reports/?id=21 [accessed 31 March 2017].

Allen, L. (2004), 'The Basel Capital Accords and International Mortgage Markets: A Survey of the Literature', Financial Markets, Institutions and Instruments, 13 (2), pp. 41-108.

Amaral, L. (2015), 'O Processo Económico' [The Economic Process], in A.C. Pinto (ed.) A Busca da Democracia: 1960-2000 [The Search for Democracy: 1960-2000] (Lisbon: Fundación MAPFRE).

Bakker, K. (2013), 'Neoliberal versus Post-neoliberal Water: Geographies of Privatization and Resistance', Annals of the Association of American Geographers, 103 (2), pp. 253-60.

Bayliss, K. (2014), 'The Financialization of Water', Review of Radical Political Economics, 46(3), pp. 277-91.

Bayliss, K., Fine, B. and Robertson, M. (2013), 'From Financialisation to Consumption: The System of Provision Approach Applied to Housing and Water', FESSUD Working Paper Series $\mathrm{n}^{\circ} 2$. Available from: http://fessud.eu/working-papers/\#WP8 [accessed 31 March 2017].

Becker, J., et al. (2010), 'Peripheral Financialization and Vulnerability to Crisis: A Regulationist Perspective’, Competition \& Change, 14 (3ロ4), pp. $225 \square 47$.

Braga de Macedo, J. (2003), 'Portugal's European Integration: The Good Student with a Bad Fiscal Constitution', South European Society and Politics, 8 (1-2), pp. 169-194. 
Casey, B.H. (2012), 'The Implications of the Economic Crisis for Pensions and Pension Policy in Europe', Global Social Policy 12 (3), pp. 246-265.

Costa, S. (2016), 'Situação Financeira das Famílias em Portugal: Uma Análise com Base nos Dados do ISFF 2013' [Financial Situation of Households in Portugal: An Analysis Based on Data from ISFF 2013], Revista de Estudos Económicos, 2 (4), pp. 15-59.

Ebbinghaus, B. (2015), 'The Privatization and Marketization of Pensions in Europe: A Double Transformation Facing the Crisis', European Policy Analysis, 1 (1), pp. 56-73.

Entidade Reguladora dos Serviços de Águas e Resíduos [ERSAR] (2012), Relatório Anual do Sector de Águas e Resíduos em Portugal [Annual Report of Water and Waste Sector in Portugal] (Lisbon: Entidade Reguladora dos Serviços de Águas e Resíduos). Available from: http://www.ersar.pt/Website en/ViewContent.aspx?SubFolderPath=\%5cRoot\%5cContents\%5cSiteEN $\% 5 \mathrm{cMenu}$ Main\%5cDocumentation\%5cERSAR Publications\&Section=Menu Main\&BookTypeID= $3 \&$ FolderPath $=\% 5$ cRoot $\% 5$ cContents $\% 5$ SiteEN $\% 5 \mathrm{cMenu}$ Main $\% 5 \mathrm{cDocumentation} \&$ BookCategory $\underline{\mathrm{ID}=1}$ [accessed 31 March 2017].

Entidade Reguladora dos Serviços de Águas e Resíduos [ERSAR] (2014), Relatório Anual do Sector de Águas e Resíduos em Portugal [Annual Report of Water and Waste Sector in Portugal] (Lisbon: Entidade Reguladora dos Serviços de Águas e Resíduos). Available from: http://www.ersar.pt/Website en/ViewContent.aspx?SubFolderPath=\%5cRoot $\% 5$ cContents $\% 5 c$ SiteEN $\% 5 \mathrm{cMenu}$ Main\%5cDocumentation\%5cERSAR Publications\&Section=Menu Main\&BookTypeID= $\underline{3 \& \text { FolderPath }=\% 5 \mathrm{cRoot} \% 5 \mathrm{cContents} \% 5 \mathrm{cSiteEN} \% 5 \mathrm{cMenu} \text { Main } \% 5 \mathrm{cDocumentation} \& \text { BookCategory }}$ $\underline{\mathrm{ID}=1}$ [accessed 31 March 2017].

Epstein, G. A. (ed) (2005), Financialization and the World Economy, (Aldershot: Edward Elgar).

European Central Bank [ECB] (2016), 'The Eurosystem Household Finance and Consumption Survey: Results from the Second Wave', ECB Statistics Paper Series $\mathrm{n}^{\circ} 18$.

European Commission [EC] (2006), Adequate and Sustainable Pensions: Synthesis Report, (Luxembourg: Office for Official Publications of the European Communities).

European Commission [EC] (2012), The 2012 Ageing Report: Economic and budgetary projections for the EU27 Member States (2010-2060), European Economy 2/2012 (Luxembourg: Office for Official Publications of the European Communities). 
European Credit Research Institute [ECRI] (2014), 'Lending to Households in Europe 1995-2013', ECRI Statistical package 2013 (Brussels: European Credit Research Institute).

Fernandez, R. and Aalbers, M.B. (2016), 'Financialization and Housing: Between Globalization and Varieties of Capitalism', Competition \& Change, 20 (2), pp. 71-88.

Fernandez, R., Hofman, A. and Aalbers, M.B. (2016), 'London and New York as a Safe Deposit Box for the Transnational Wealth Elite, Environment and Planning A, 48 (12), pp. $2443-61$.

Ferreira do Amaral, J. (2009), Estudo sobre a Evolução Recente e o Futuro da Economia Portuguesa [Study on the Recent Evolution and Future of the Portuguese Economy], (Lisbon: UGT).

Fine, B. (2010), 'Locating financialisation', Historical Materialism, 18(2), pp. 97-116.

Fine, B. and Saad-Filho, A. (2016), 'Thirteen Things You Need to Know About Neoliberalism', Critical Sociology, Published online before print August 4, 2016, doi: 10.1177/0896920516655387

Fligstein, N. and Goldstein, A. (2015), 'The Emergence of a Finance Culture in American Households, 1989-2007', Socioeconomic Review, 13 (3), pp. 575-601.

Gambarotto, F. and Solari, S. (2015), 'The Peripheralization of Southern European Capitalism within the EMU', Review of International Political Economy, 22 (4), pp. 788-812.

Instituto da Habitação e Reabilitação Urbana [IHRU] (2015a), 1987-2011: 25 Anos de Esforço do Orçamento do Estado com a Habitação [1987-2011: 25 Years of Housing State Budget], (Lisbon: Instituto da Habitação e Reabilitação Urbana). Available from: https://www.portaldahabitacao.pt/opencms/export/sites/ihru/pt/ihru/docs/Esforco-do-Estado-emHabitacao.pdf [accessed 31 March 2017].

Instituto da Habitação e Reabilitação Urbana [IHRU] (2015b), Habitação: Estratégia Nacional para a Habitação [Housing: National Strategy for Housing], (Lisbon: Instituto da Habitação e Reabilitação Urbana). Available from: https://www.portaldahabitacao.pt/opencms/export/sites/portal/pt/portal/habitacao/EstNacHabitacao/Est rategia-para-a-habitacao.pdf [accessed 31 March 2017].

Instituto de Gestão de Fundos de Capitalização da Segurança Social [IGFCSS] (2014) Relatório de Gestão do Fundo de Estabilização Financeira da Segurança Social 2013 [Report of Management of Social Security Financial Stabilisation Fund 2013], (Lisbon: IGFCSS).

Instituto de Seguros de Portugal (ISP) (2007), Relatório do Sector Segurador e dos Fundos de Pensões, [Report of the Sector of Insurance and Pensions Fund], (Lisbon: ISP). Available from: 
http://www.asf.com.pt/NR/exeres/1BCE3171-23D8-429F-B59E-E2C1F75788E5.htm [accessed 31 March 2017].

Instituto de Seguros de Portugal (ISP) (2010), Relatório do Sector Segurador e dos Fundos de Pensões, [Report of the Sector of Insurance and Pensions Fund], (Lisbon: ISP). Available from: http://www.asf.com.pt/NR/exeres/1BCE3171-23D8-429F-B59E-E2C1F75788E5.htm [accessed 31 March 2017].

Instituto de Seguros de Portugal (ISP) (2013), Relatório do sector segurador e dos fundos de pensões, [Report of the Sector of Insurance and Pensions Fund] (Lisbon: ISP). Available from: http://www.asf.com.pt/NR/exeres/1BCE3171-23D8-429F-B59E-E2C1F75788E5.htm [accessed 31 March 2017].

Instituto Nacional de Estatísticas [INE] (2012), Evolução do Parque Habitacional em Portugal 20012011 [Housing Stock Evolution in Portugal: 2001-2011], (Lisbon: INE). Available from: https://www.ine.pt/xportal/xmain?xpid=INE\&xpgid=ine publicacoes\&PUBLICACOESpub boui=14 9380925\&PUBLICACOESmodo=2\&xlang=pt [accessed 31 March 2017].

Kemp, P. A. (2015), 'Private Renting After the Global Financial Crisis', Housing Studies, 30 (4), pp. 601-20.

Lapavitsas, C. (2013), Profiting Without Production: How Finance Exploits Us All (London: Verso).

Lapavitsas, C. and Powell, J. (2014), 'Financialisation Varied: A Comparative Analysis of Advanced Economies', Cambridge Journal of Regions, Economy and Society, 6 (3), pp. 359-79.

Lapavitsas, C., Kaltenbrunner, A., Lambrinidis, G., Lindo, D., Meadway, J., Michell, J.; Painceira, J. P., Pires, E., Powell, J., Stenfors, A., Teles, N. and Vatikiotis, L. (2012), Crisis in the Eurozone (London: Verso).

López, I. and Rodríguez, E. (2011), ‘The Spanish Model', New Left Review, 69, 5-29.

Louçã, F. (2011), Portugal Agrilhoado - A Economia Cruel na Era do FMI [Portugal in Chains - Cruel Economy in the IMF Era] (Lisbon: Bertrand).

Matos, F.L. (2012), 'Recent Dynamics in the Portuguese Housing Market as Compared with the European Union', Bulletin of Geography. Socio-Economic Series, 18, pp. 69-84.

Mendes, F. (2011), Segurança Social: O Futuro Hipotecado [Social Security: Mortgaged Future] (Lisbon: Fundação Francisco Manuel dos Santos). 
Mendes, H. and Albuquerque, J.L. (2014), 'Segurança Social: As Pensões como Retribuição do Trabalho e como Responsabilidade Solidária [Social Security: Pensions as Labour Retribution and Solidary Responsibility], in A. Barata, and R. Carmo (eds), Estado Social: De Todos Para Todos [Welfare State: From All to All] (Lisbon: Tinta da China), pp. 135-166.

Orsi, L. and Solari, S. (2010), 'Financialisation in Southern European Countries', Economie Appliquee 63(4), pp. 5-34.

Pato, J. (2011), História das Políticas Públicas de Abastecimento e Saneamento de Águas em Portugal [History of Public Policy on Water Provision and Treatment in Portugal] (Lisbon: ERSAR/ICS).

Pedras, R. (2000), A Gestão dos Fundos de Pensões em Portugal [The Management of Pension Funds in Portugal], Cadernos do Mercado de Valores Mobiliários, $\mathrm{n}^{\circ} 8$ (Lisbon: CMVM).

Robertson, M. (2014), 'Case Study: Finance and Housing Provision in Britain', FESSUD Working Paper Series $\mathrm{n}^{\circ}$ 51. Available from: http://fessud.eu/wp-content/uploads/2013/04/Case-Study_Finance-and-Housing-Provision-in-Britain-working-paper-51.pdf [accessed 31 March 2017].

Rodrigues, J. and Reis, J. (2012), 'The Asymmetries of European Integration and the Crisis of Capitalism in Portugal', Competition \& Change, 16 (3), pp. 188-205.

Rodrigues, J., Santos, A.C. and Teles, N. (2016a), 'Semi-peripheral Financialisation: The case of Portugal', Review of International Political Economy, 23(3), pp. 480-510.

Rodrigues, J., Santos, A.C. and Teles, N. (2016b), 'Financialisation of Pensions in Europe: Systemic and Variegated Effects in Semi-Peripheral Portugal', FESSUD Working Paper Series, n 175, Available from: http://fessud.eu/wp-content/uploads/2015/03/FESSUD_WP175_Financialisation-Pensions-inEUVariegated-Effects-in-Portugal.pdf [accessed 31 March 2017].

Royo, S. (2010), 'Portugal and Spain in the EU: Paths of Economic Divergence (2000-2007)', Análise Social, 45 (195), pp. 209-54.

Royo, S. (2013), 'Portugal in the European Union: The Limits of Convergence', South European Society and Politics, 18 (2), pp. 197-216.

Santos, A.C. and Teles, N. (2016), 'Recent Trends in Household Financial Behaviour', FESSUD Working Paper Series $\mathrm{n}^{\mathrm{o}}$ 171. Available from: http://fessud.eu/wpcontent/uploads/2015/03/FESSUD WP171_Recent-Trends-Household-Financial-Behaviour.pdf [accessed 31 March 2017]. 
Santos, A.C., Serra, N., and Teles, N. (2015), 'Finance and Housing Provision in Portugal', FESSUD Working Paper Series $\mathrm{n}^{\mathrm{o}}$ 79. Available from: http://fessud.eu/wpcontent/uploads/2015/01/FESSUD_Working-Paper-Series_Santos-Serra-Teles-2015-79.pdf [accessed 31 March 2017].

Schwartz H.M and Seabrooke L. (eds) (2009), The Politics of Housing Booms and Busts. (Basingstoke: Palgrave Macmillan).

Serra, N. (2002), Estado, Território e Estratégias de Habitação [State, Territory and Housing Strategies] (Coimbra: Quarteto).

Teles, N. (2015), 'Financialisation and Neoliberalism: The Case of Water Provision in Portugal', FESSUD Working Paper Series $\mathrm{n}^{\mathrm{o}}$ 102. Available from: http://fessud.eu/wpcontent/uploads/2015/03/Financialisation-and-neoliberalism-the-case-of-water-provision-in-Portugalworking-paper-102.pdf [accessed 31 March 2017].

Teles, N. (2016), 'Prospects for Financialised Water Provision: Going Beyond Public/Private Ownership', FESSUD Working Paper Series $\mathrm{n}^{\circ}$ 177. Available from: http://fessud.eu/wpcontent/uploads/2015/03/FESSUD WP177 Financialised-water-provision-beyond-public-privateownership-debates.pdf [accessed 31 March 2017].

Teles, N. (2016), 'Prospects for Financialised Water Provision: Going beyond Public/private Ownership Debates', FESSUD Working Paper Series $\mathrm{n}^{\circ}$ 177. Available from: http://fessud.eu/wpcontent/uploads/2015/03/FESSUD_WP177_Financialised-water-provision-beyond-public-privateownership-debates.pdf [accessed 31 March 2017].

Torres, F. (2009), 'Back to External Pressure: Policy Responses to the Financial Crisis in Portugal', South European Society and Politics, 14 (1), pp. 55-70.

van der Zwan, N. (2014), 'Making Sense of Financialization', Socioeconomic Review, 12 (1), pp. 99129.

* The research leading to these results received funding from the European Union Seventh Framework Programme (FP7/2007-2013), through the FESSUD project (grant agreement number 266800), and from the Portuguese Foundation for Science and Technology (FCT/MEC), cofinanced by the ERDF through the Competitiveness and Innovation Operational Programme COMPETE 2020, through the FINHABIT project (PTDC/ATP-GEO / 2362/2014 - POCI-010145-FEDER-016869). Grateful thanks are due to Ben Fine and Giuseppe Fontana for comments 
on an earlier version of this paper, and to three anonymous reviewers. All remaining errors or omissions are our own responsibility. Contact: anacsantos@ces.uc.pt.

${ }^{\dagger}$ Centre for Social Studies (CES), University of Coimbra, Portugal. E-mail: anacsantos@ ces.uc.pt ¥ Faculty of Economics (FEUC) and Centre for Social Studies (CES), University of Coimbra, Portugal. E-mail: joaorodrigues@ces.uc.pt

${ }^{\S}$ Centre for Social Studies (CES), University of Coimbra, Portugal. E-mail: nunoteles@ ces.uc.pt ${ }^{5}$ This contrasts with the Variety of Capitalism literature as applied, for instance, to housing (e.g. Schwartz and Seabrooke 2009), which is not as apt for examining the dynamic nature of the interaction between global finance and national housing markets (cf. Fernandez and Aalbers 2016).

${ }^{6}$ The concept of loanable capital is here taken from Lapavitsas (2013). This is a derivation of the concept of interest bearing capital, which can be hoarded from both the circuits of production and personal income, expanding the concept to all lending activity, namely household lending (for a more extensive account see Rodrigues et al. 2016a).

${ }^{7}$ See Rodrigues et al. (2016a) for a more developed account of the financialisation trajectory of the Portuguese economy.

${ }^{8}$ In 2008, the year the GFC hit, total debt of non-financial corporations was $208 \%$ and of households it was $97 \%$ of GDP, which compares to an EU average of $183 \%$ and $67 \%$ respectively. Available from: http://ec.europa.eu/eurostat/tgm/table.do?tab=table\&init=1\&language=en\&pcode=tipspd25\&pl ugin=1 (accessed 31 March 2017).

${ }^{9}$ The ordered nature of the transition can be explained by the conjunction of favourable factors including: the role of the State in planning and implementing these reforms, which were carefully phased out even if within a short time span; state support of the banking sector through a highly beneficial fiscal framework; the presence of a then strong public bank (Caixa Geral de Depósitos) capable of intervening at convenient and troubled times; and very low levels of private indebtedness (of non-financial firms and households), meaning the presence of profitable and unexplored markets. 
${ }^{10}$ Current account balance as percentage of GDP grew from $-4.4 \%$ in 1996 to $-12.1 \%$ in 2008 .

Available

from:

http://ec.europa.eu/eurostat/tgm/table.do?tab=table\&init=1\&plugin=1\&language=en $\& p c o d e=t i p$ $\underline{\operatorname{sbp} 20}$ (accessed 31 March 2017).

${ }^{11}$ Between 1995 and 2008, the contribution of Industry to Gross Value Added declined from 19\% to $14 \%$ and the sum of Construction with Financial, insurance and real estate activities grew from $20 \%$ to 24\%. Our own calculations based on data available from http://www.pordata.pt/en/Portugal/Gross+Domestic+Product++in+terms+of+production+(2011) $\underline{-2280}$ (accessed 31 March 2017).

${ }^{12}$ Average annual Real GDP growth rate was 3.0\% during 1991-2000, 0.9\% in 2001-2005, and 0.6\% in 2006-2010. Our own calculations based on data available from: http://www.pordata.pt/en/DB/Portugal/Search+Environment/Table (accessed 31 March 2017).

${ }^{13}$ See also Ferreira do Amaral (2009).

${ }^{14}$ For a more developed debate on the causes and consequences of the Portuguese structural problems see Rodrigues and Reis (2012).

${ }^{15}$ Between 1992 and 2008 bank credit for construction and real estate activities rose from $10 \%$ to 40\% of entire bank lending to non-financial firms (Rodrigues et al. 2016a); and between 1992 and 2008 housing loans as a percentage of disposable household income rose from $23.2 \%$ to $84.5 \%$ (ECRI 2014).

${ }^{16}$ Again, this diagnosis is shared with other accounts of the Portuguese economy, (e.g. Amaral, 2015). See Santos et al. (2015) for a more developed account of the recent financialised evolution of the Portuguese housing sector.

${ }^{17}$ This contrasts with the evolution of other housing systems of provision that were equally marked by the recent growth of mortgage debt, signaling the relevance of sectoral analysis for conceptual and empirical elaborations on the variegated nature of financialisation. In the UK, for example, Britain's restrictive planning system together with the speculative nature of housebuilding has led to credit being channeled more into demand than into supply, resulting in the escalation of house prices in the country (Robertson 2014). In Spain, there was both growth 
in demand and supply, but the boom and bust in its real estate sector had no parallel with the Portuguese (López and Rodríguez 2011).

18 From an annual total of 68,825 to 125,708 . Available from: http://www.pordata.pt/en/Portugal/Completed+dwellings+in+new+constructions+for + family $+\mathrm{h}$ ousing+total+and+by+dwelling+typology-189 (accessed 31 March 2017).

${ }^{19} 12.5 \%$ of vacant housing units in 2011 . Our own calculations based on data available from: http://www.pordata.pt/en/Portugal/Conventional+dwellings++according+to+the+Census+total+ and+by+form+of+occupation-146 (accessed 31 March 2017).

${ }^{20}$ Homeownership represented $73 \%$ of accommodation in 2011, growing from $65 \%$ in 1991, and 57\% in 1981. Available from: http://www.pordata.pt/en/DB/Portugal/Search+Environment/Table (accessed 31 March 2017).

${ }^{21}$ This together with the economic stagnation of the 'lost decade' might help explain the cooling of the housing bubble in Portugal relative to what was observed in Spain. http://www.bportugal.pt/EstatisticasWEB/(S(wdepob45cnfsem45pfsnwp55))/SeriesCronologica $\underline{\text { s.aspx }}$ (accessed 31 March 2017).

${ }^{23}$ This has also contributed to the relatively smooth, undisturbed financial expansion, as mentioned above, as well as to the more moderate impact of the crisis on the Portuguese housing sector, which did not experience the dramatic consequences of the housing bubbles of the USA or Spain. For the distribution of mortgages across socio-demographic groups in the EU see ECB (2016), and in the USA see Fligstein and Goldstein (2015).

${ }^{24}$ For example, between 2001 and 2011 the monthly value of acquired homes rose $36 \%$ while the monthly cost of rented accommodation rose 91\% (INE 2012).

${ }^{25}$ For example, in Lisbon, in the first quarter of 2016, foreign investment represented $20 \%$ of residential transactions, with a predominance of French (26\%), British (18\%) and Chinese (13\%) buyers. Available from: https://www.publico.pt/economia/noticia/fanceses-lideram-compras-deimobiliario-portugues-superando-ingleses-e-chineses-1732517 (accessed 31 March 2017). 
${ }^{26}$ Between 2012 and 2015 the price of flats in Lisbon rose 22\%, much higher than the national average of $5 \%$, which is explained precisely by the purchase of housing for tourism, namely for short-term rental. Available from: https://www.publico.pt/economia/noticia/preco-das-casas-emlisboa-subiu-22-em-tres-anos-1732773 (accessed 31 March 2017).

${ }^{27}$ This results from recent reforms carried out in virtually all EU countries seeking to control public expenditure with pensions and boost financial markets, implying cuts in State pay-as-yougo and defined benefit pensions and the promotion of prefunded capitalised forms of private pensions markets (Ebbinghaus 2015). However, the situation of the different countries is varied, betraying once again the different points of departure and the path dependence of institutional change. For example, in 2013, the percentage of households with voluntary pensions and whole life insurance was $46.3 \%$ in Germany and $17.2 \%$ in Portugal, for a EU20 average of around $30.3 \%$ (ECB 2016).

${ }^{28}$ In 2013, while $17.2 \%$ of Portuguese households had voluntary pensions and whole life insurance, as we have seen, about twice as many households, $34.7 \%$, had mortgage debt (ECB 2016). Net equity of households in life insurance and in pension funds reserves represented $35 \%$ of GDP in 2012, compared to an EU average of $75 \%$. Available from: http://appsso.eurostat.ec.europa.eu/nui/submitViewTableAction.do (accessed 31 March 2017).

29 Available from: http://www.pordata.pt/en/Portugal/Social+security+expenditure+as+percentage+of+GDP-705 (accessed 31 March 2017).

30 Available from: http://www.pordata.pt/en/Portugal/Social+Security+pensions+total++survivors+pensioners++di

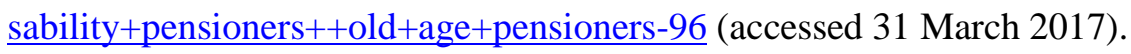

31 Available from: http://www.pordata.pt/en/Portugal/Social+Security+pensions+as+percentage+of+GDP+total+ex penditure+and+by+type-942 (accessed 31 March 2017). 
http://www.pordata.pt/en/Portugal/Disability+and+old+age+pensioners+of+the+general+Social + Security+scheme+with+pensions+below+the+national+minimum+wage+(percentage) -2007 (accessed 31 March 2017).

${ }^{33}$ In fact, this situation only changed as a result of falling employment rates in recent years.

${ }^{34}$ See Rodrigues et al. (2016b) for a more developed account of pension reform in Portugal.

${ }^{35}$ In 2007, prior to the international financial crisis, $64.5 \%$ of insurance companies' investments in PPRs were applied in the EU, and only $14 \%$ in Portugal (ISP 2007).

${ }^{36}$ See Teles $(2015,2016)$ for a more developed account of the recent evolution of water provision in Portugal.

${ }^{37}$ These values were legally established in the mid-1990s and based on the 10-year government bond market rate to which was added a 'risk premium' of 3\% (Teles 2015). 